\title{
СТЕФАН СТАМБОЛОВ И ЗАХАРИЙ СТОЯНОВ
}

\section{М. Куманов}

Куманов М. Стефан Стамболов і Захарій Стоянов. У статті розглядаються взаємовідносини між двома яскравими особистостями болгарського політикуму - Стефаном Стамболовим і Захарієм Стояновим. Автор акцентує увагу на протиріччях між ними під час прем'єрства Стамболова.

Ключові слова: Ст. Стамболов; 3. Стоянов; Болгарське Відродження; Народно-ліберальна партія.

Куманов М. Стефан Стамболов и Захарий Стоянов. В статье рассматриваются взаимоотношения между двума яркими личностями болгарского политикума - Стефаном Стамболовым и Захарием Стояновым. Автор акцентирует внимание на противоречиях между ними во время премьерства Стамболова.

Ключевые слова: Ст. Стамболов; 3. Стоянов; Болгарское Возрождение; Народнолиберальная партия.

Kumanov M. Stefan Stambolov and Zakharii Stoyanov. The article deals with the relationship between two outstanding personalities of the Bulgarian political elite - Stefan Stambolov and Zakharii Stoyanov. The author focuses on the contradictions beween them during the premiership of Stambolov.

Keywords: St. Stambolov; Z. Stoyanov; Bulgarian Revival; People's Liberal Party.

Една от личностите във възрожденската и следосвобожденската епоха, с която се преплитат твърде много пътищата на Стефан Стамболов, е и Захарий Стоянов. И това не е никак случайно, като имаме предвид сложния и противоречив път, който двамата именити дейци извървяват като революционери и общественици. Въпреки излезлите не малък брой публикации както за единия, така и за другия ${ }^{1}$, не ни е известно специално изследване, посветено на техните взаимни отношения. В този смисъл настоящото съобщение е пръв опит в тази насока. То не претендира за изчерпателност, а по-скоро цели да проследи в най-сбита форма по-важните моменти от съвместната им дейност. Макар че тя продължава по-малко от две десетилетия, в нея могат да се откроят два главни етапа: първи - до Освобождението на България от османско иго, и втори - от Освобождението до смъртта на Захарий Стоянов през 1889 г.

Твърде различен е началният старт на жизнения им пьт - Ст. Стамболов е роден в Търново (дн. Велико Търново), град с богата история не само по време на Второто българско царство, но и през Българското възраждане, а Захарий Стоянов - в едно малко селце Медвен, скътано дълбоко в пазвите на Източна Стара планина, в съседство с историческото с. Жеравна и недалече от гр. Котел, един от центровете на Българското възраждане. Различна е и семейната им среда - докато бащата на първия, заедно с чичо му търгуват със стоки чак в Цариград (Стамбол), (от който град получават и своето прозвище Стамболови), бащата на втория е обикновен селянин. Докато родителите на Стефан Стамболов скланят пред молбите на учителя Т. Шишков, впечатлен от голямото ученолюбие на тяхното дете, да продължи образованието си в Русия, бащата на Захарий, по собствените признания на самия Захарий, се оказал открит противник на учението на своя син.

Едва 16-годишен, младият тьрновски юноша поема пътя за „обетованата земя“ (Русия) и пристига в гр. Одеса, където постъпва като ученик в известната Семинария, в която преди него учили и други българчета като Васил Друмев (получил по-голяма известност с духовното име Климент), взел активно участие в обществено-политическия живот на България както преди, така и след Освобождението ѝ. Това, че не успява да завърши пълния курс на обучението в Семинарията, се дължи само на причини от лично естество, предизвикани от самия Стефан Стамболов. За медвенчето, след като вратите на училището са затворени, остават два пътя, подобно на неговите съселянчета - занаят или овчарльк. И той поема по втория, поради което юношеските му години са свързани с равна Добруджа, където се отглеждат стадата на многобройни планинци не само от с. Медвен, но и от редица други села на Котленския край.

Това, което е отличителна черта и за двамата през първия етап от жизнения им път, е голямата им страст към самообразованието. Защото след изключването му от Одеската

(C) Куманов, М., 2015

232 
семинария, за Стефан Стамболов също няма друг път за интелектуалното му развитие, освен сам да попълва знанията си. За Захарий Стоянов този път се оказва единственият, не само да се ограмоти, но и да се издигне в интелектуално отношение.

Следва да се изтъкне, че благодарение на голямата си упоритост, която е сред отличителните черти и на двамата, те наистина постигат забележителни успехи в тази насока: Стефан Стамболов става поет и публицист, а Захарий Стоянов - само публицист, но от най-талантливите, които се появяват на журналистическото поле в първите години след Освобождението. Перото за Стефан Стамболов е другият „ятаган“, с който той си служи и като революционер, и като обществен, политически и държавен деец.

Запознанството им става съвсем случайно и при твърде неочаквани обстоятелства. През лятото на 1873 г., по време на лятната ваканция на път от Одеската семинария за Търново, Стефан Стамболов, пътуващ заедно със своя другар и земляк Иван Панов Семерджиев, който по-късно ще стане и негов съратник в революционната борба, посещават гр. Русе, където гостуват на легендарната баба Тонка. Тази чест им е оказана като познати и приятели на нейния син Георги, който по онова време учи в Юнкерското училище в Одеса.

В крайдунавския град двамата търновци се задържат за кратко време, но то е съвсем достатъчно, за да се запознаят с местните революционни дейци, чийто център е градското читалище „Зора“. В него като библиотекар работи другият син на баба Тонка - Никола Обретенов, чиято жизнена съдба от този момент до трагичната гибел на Стефан Стамболов през 1895 г. ще се преплита многократно по различни поводи. Захарий Стоянов се оказва в Русе преди Ст. Стамболов по съвършено други причини, които той подробно е описал в знаменитото си съчинение „Записки по българските въстания“.

Тази първа среща изобщо не подсказва, че ще се превърне в отправна точка за бъдещата им съвместна дейност и като революционери, а след Освобождението - и като общественици. Така вървят нещата до лятото на 1875 г. През това време Ст. Стамболов напуска преждевременно Одеската семинария и пред реалната опасност да попадне в рьцете на руската охранка, заради контакти с „нихилистични“ кръгове в черноморския град, е принуден да търси спасение с бягство вън от пределите на империята. След дълги митарства успява да се завърне в родния си град и веднага установява контакт с местните революционни дейци. За кратко време се налага като авторитетна личност, заради което е издигнат за ръководител на революционния комитет.

Началната му дейност като революционер съвпада с твърде труден момент в българското революционно движение. След обесването на Васил Левски настьпва голямо униние в редовете дори и на българската революционна емиграция в съседна Румъния. Сам председателят на Българския революционен централен комитет Любен Каравелов е вече обезверен и тръгва по пътя на просветителството. В Българско много от създадените дори и с личното участие на Апостола революционни комитети заглъхват и прекратяват съществуването си.

В същото време обстановката на Балканския полуостров е крайно неспокойна - в Херцеговина и Босна избухва въстание. Това дава кураж на друга група български революционни дейци около Христо Ботев да продължат делото на Апостола.

Стефан Стамболов няма възможност лично да се запознае с ръководителя на Вътрешната революционна организация, защото когато той увисва на бесилото, младият търновец е още семинарист в Одеса. Когато обаче поема пьтя на революционната борба, той своевременно узнава за неговата личност и дело, то става и негова жизнена съдба.

Когато Атанас Узунов, първият заместник на Васил Левски, е заловен във връзка с Хасковското приключение и изпратен на заточение, изниква въпросът за следващ такъв. Случаят отрежда тази висока чест на Стефан Стамболов. Биографите му са единодушни, че той се заема с голям жар с възложената му голяма, трудна и твърде рисковата мисия. Само за няколко месеца обикаля редица селища в Търновско и Габровско, дори се прехвърля и на юг от Балкана, където с помощта на отец Матей Преображенски и други свои приятели възстановява стари и основава нови революционни комитети.

Отварям една малка скоба. Пръв преди повече от половин столетие покойният проф. Александър Бурмов, един от авторитетните изследователи не само на Българското средновековие, но и на революционните борби през 60-те и 70-те години на XIX в., обоснова тезата, че след Ат. Узунов следващият заместник на Апостола е бил именно Ст. Стамболов $^{2}$. Направеният опит преди около двадесетина години от един шуменски историк, бивш 
уредник на родната къща на Панайот Волов, да докаже, че не Ст. Стамболов, а П. Волов станал заместник на В. Левски굴 не можа да се наложи поради неубедителните аргументи, изложени от него.

Преминавам по-нататък. Като заместник на Апостола, Ст. Стамболов посещава няколкократно Букурещ и установява трайни и близки контакти с Хр. Ботев. Най-яркото доказателство за техните отношения е съвместната им стихосбирка „Песни и стихотворения“, която издават през 1875 г. От двадесетината стихотворения, колкото съдържа тази стихосбирка, творбите на Ст. Стамболов в нея наброяват не повече от пет-шест. В художествено отношение те са далеч под нивото на гениалните стихове на Хр. Ботев. Но ако Хр. Ботев не е могъл някак да му предаде от своя поетичен дар, той е оказал неизмеримо влияние върху революционното му съзряване. Всеки, който се запознае със стихотворението „Не щеме ний богатство, не щеме ний пари“, ще се убеди сам в това твърдение.

Известно е също така, че Ст. Стамболов питае голям респект и към личността на Любен Каравелов - председател на БРЦК и редактор на неговите печатни органи „Свобода““ и „Независимост“. Когато обаче последният решава да се оттегли от революционната борба, Ст. Стамболов без колебание застава на страната на Хр. Ботев.

Изследователите на Старозагорското въстание от 1875 г. са единодушни, че най-решителният поддръжник на Хр. Ботев за въстание в България е именно Ст. Стамболов. Въпреки краткото време, с което разполага, той отново успява да покаже големите си качества като организатор. От трите окръга в Българско, въстанието от лятото на 1875 г. благодарение на неговите организаторски качества се оказва най-добре подготвено в Старозагорския ${ }^{4}$. Изтъкваме този момент нарочно, тъй като по време на Старозагорското въстание пътищата на Ст. Стамболов и Захарий Стоянов отново се преплитат и оставят вече трайна диря върху тяхната по-нататъшна дружба и приятелство.

След неуспеха на въстанието от лятото на 1875 г. Ст. Стамболов успява да се прехвърли в Румъния. Захарий Стоянов се укрива на различни места в Българско до пролетта на следващата 1876 г.

Случайно стекли се обстоятелства отново изтласкват Ст. Стамболов на преден план в революционната борба. Както се знае, група по-млади революционни дейци решават да продължат делото на старозагорци. За да избегнат унинието, завладяло за втори път българската революционна емиграция в Букурещ, те се установяват в крайдунавския градец Гюргево и в края на 1875 г. в продължение на месец-месец и половина изработват плана за подготовката на новото въстание в Българско, което да бъде обявено през пролетта на следващата година ${ }^{5}$. Душата на този комитет, или Апостолско събрание, както е по-точно неговото наименование ${ }^{6}$, е Ст. Стамболов. Той е определен и за апостол на бъдещото въстание в родния му Търновски край. Захарий Стоянов също не се отказва от революционната борба. Привлечен е от Панайот Волов за негов помощник в Пловдивски (или както е повече известен - Панагюрски) революционен окръг.

След неуспеха и на Априлското въстание от 1876 г., оцелял по чудо, Ст. Стамболов отново търси спасение в съседна Румъния. Захарий Стоянов, който придружава Георги Бенковски до неговото убийство в Рибаришкия балкан, е заловен от османска потеря след известно време и е разкарван из различни затвори. Успял да се отърве от тях, се прибира в родното си село, но скоро след това отново се насочва към Русе, където са неговите близки другари и приятели.

До избухването на Руско-турската война от 1877-1878 г. Ст. Стамболов се скита „немил-недраг“" хъш в румънската столица. Тежките условия на живот обаче ни най-малко не повлияват на революционния му дух. Приема предложението на стария Бльсков и се заема с редактирането на последния Ботев вестник „Нова България““, който излиза до обявяването на Освободителната война през април 1877 г. Заедно с това влиза и в състава на Българското централно благотворително общество, което се опитва да продължи делото на БРЦК ${ }^{8}$

След обявяването на войната между Русия и Османската империя през април 1877 г. Ст. Стамболов не последва примера на повечето от своите събратя хъшове в Букурещ и други румънски градове, и въпреки енергичните им подканяния, не постъпва в редовете на Българското опълчение. Това съвсем не означава, че е имал намерение да остане като страничен наблюдател на събитията, които коренно ще преобърнат съдбата на българския народ. Доказателството за това е, че приема поканата да стане сътрудник на някои руски вестници и да отразява развоя на военните действия на руската армия на юг от р. Дунав. 
Тази мисия той изпълнява с успех 9 . В същото време е привлечен и за доставчик на храни за руската армия. Поемайки тази задача, той се сеща за своя съратник от Старозагорското въстание Захарий Стоянов и го привлича за свой помощник. Така, за трети път съдбата отново среща двамата дейци.

След Освобождението пътищата им за известно време се разделят, тъй като, бидейки още в плен на своите революционни идеи, Стефан Стамболов тръгва отново по пътя на революционната борба като един от главните организатори и ръководители на Кресненско-Разложкото въстание от $1878-1879$ г. $^{10}$. Още преди въстанието да загльхне напълно, той е избран за депутат в Учредителното събрание, което ще заседава в Търново. По тази причина в началото на 1879 г. се озовава в родния си град. За негова голяма неприятна изненада узнава, че по волята на великите сили той и другите избрани от Македония и Тракия депутати няма да бъдат допуснати до участие в изработването на основния закон, по който ще се управлява в бъдеще освободеното Княжество. Въпреки това отново не остава със скрьстени ръце. От една страна, е в ежедневни контакти с депутатите от либералното течение и изказва мнения по обсъжданите в Събранието въпроси. По този начин, макар и косвено, допринася също за демократичния дух на Търновската конституция. От друга страна, подпомага списването на в. „Остен“, издаван по време на заседанията на Учредителното събрание от Петко Рачов Славейков, също в Търново ${ }^{11}$.

След закриването на Учредителното събрание от 1879 г. Ст. Стамболов остава за известно време в старопрестолния град, след което решава да се премести в София, където да търси каквато и да е служба за своето препитание. И наистина, получава някаква дребна служба в едно от министерствата, но бързо се отказва от нея и се залавя отново за перото. Сътрудничи на органите на Либералната партия, а след това започва да издава и свой вестник. През това време вече е претърпял значителна идейна еволюция надясно, като от революционни преминава на либерални позиции. Става привърженик на Либералната партия и в това си качество се изявява като яростен защитник на Търновската конституция. Това обаче не му попречва да пренебрегне някои от нейните повели, които се отнасят до собствената му личност. Без да притежава изискваната от същата тази конституция възраст, кандидатира се за депутат във Второто обикновено народно събрание и дори е избран за един от неговите подпредседатели.

Ст. Стамболов се обявява решително против извършения държавен преврат от 27 април 1881 г. и последвалия след него режим на пълномощията. Въпреки големия риск да попадне под ударите на новите управници, отказва да емигрира от Княжеството, както това правят Петко Каравелов, П. Р. Славейков и други дейци на Либералната партия. Препитава се отново с журналистика.

В началото на 80-те години на XIX в. Ст. Стамболов питае искрено уважение към тримата водачи на Либералната партия - Драган Цанков, П. Р. Славейков и Петко Каравелов. Не крие възхищението си от поведението на първия, който стоически понася ударите на режима на пълномощията, и дори му посвещава едно свое стихотворение. Затова е крайно изненадан от започналите борби вътре в партията, довели през лятото на 1884 г. до нейното разцепление ${ }^{12}$.

Какво става през това време със Захарий Стоянов? След като се установява в Русе, той също тьрси дребни служби за препитание. Главното му внимание обаче е насочено в друга посока - издирване и събиране на материали за своите „Записки“ и за други исторически съчинения, които е намислил да подготви - биографии за Васил Левски, Хр. Ботев, както и за революционните движения през 60-те и 70-те години на XIX в., допринесли в последна сметка за освобождението на България. В идейно отношение както Ст. Стамболов, така и Захарий Стоянов еволюира от революционните си възгледи и преминава на радикални, а по-късно и на либерални позиции.

След установяването на режима на пълномощията, за разлика от Др. Цанков и Ст. Стамболов, Захарий Стоянов емигрира в Източна Румелия. Това му дава възможност да се запознае по-отблизо с духа на българите от областта и да застане начело на тяхната борба за присъединяване към Княжеството. Както е известно, възглавява Българския таен централен революционен комитет, който изиграва главна роля за подготовката и извършването на Съединението от септември 1885 г. ${ }^{13}$

Година преди това, през май 1884 г., в Княжеството се провеждат изборите за IV Обикновено народно събрание, които бележат финалната развръзка между Др. Цанков, от една 
страна, и П. Каравелов (заедно с П. Р. Славейков), от друга. В така създалата се трудна ситуация Ст. Стамболов е заставен да вземе окончателно решение към кое от двете течения да се ориентира. Изборът му е твърде мъчителен и изпълнен с големи душевни терзания, тъй като, както вече се изтъкна, той питае еднакви симпатии към водителите и на двете течения. В последна сметка, нарежда се под знамето на П. Каравелов, което му осигурява и председателското място на IV Обикновено народно събрание ${ }^{14}$.

Като парламентарен шеф Ст. Стамболов посреща с нескривана радост и възторг извършеното в началото на септември 1885 г. Съединение на Източна Румелия с Княжество България и заедно с министър-председателя П. Каравелов придружават княз Александър I Батенберг до Пловдив, където той е провъзгласен за княз на двете Българии. Въпреки високия пост, който заема, след избухването на Сръбско-българската война от 1886 г. напуска незабавно столицата и се озовава на бойното поле при Сливница и Драгоман ${ }^{15}$.

До лятото на 1886 г. Ст. Стамболов е твърд следовник на П. Каравелов. Пьтищата им се разминават и отдалечават след детронирането на княз Александър I Батенберг. За разлика от министьр-председателя, след като узнава, че някои от войсковите части не одобряват извършения държавен преврат, застава начело на контрапреврата. От този момент се поставя началото на последния етап от обществено-политическа дейност на Ст. Стамболов, когато той се издига като първостепенна фигура в цялостния обществено-политически живот на страната - отначало като член на Регентския съвет, а от август 1887 до май 1894 г. и като министьр-председател ${ }^{16}$.

Застанал начело на държавното кормило, Ст. Стамболов отново не забравя за Захарий Стоянов. Отправя към него покана да се заеме със списването и редактирането на в. „Свобода“. Последният приема поканата и влага целия си журналистически и публицистичен талант. Благодарение на него и на таланта на Дим. Петков, вестникът се издига до равнището на флагман на българската журналистика през втората половина на 80-те години на XIX в. За голямо съжаление, участието на двамата във в. „Свобода“ не продължава дълго, тъй като Ст. Стамболов им възлага и други задачи - в продължение на 7 години Дим. Петков е столичен кмет и председател на Централното бюро на Народнолибералната партия. Известно време възглавява и Народното събрание, а малко преди падането на Ст. Стамболов от власт е и министър в неговия кабинет ${ }^{17}$. Зах. Стоянов е издигнат отначало за един от подпредседателите на V Обикновено народно събрание, а след това - и за негов председател. На този висок държавен пост го заварва смъртта в началото на септември 1889 г., когато е на посещение в Париж.

През периода 1886-1889 г. отношенията между Ст. Стамболов и Зах. Стоянов съвсем не са гладки, колкото и невероятно да изглежда това. Разбира се, по главните насоки на вътрешната и външната политика между тях няма разномислие. Ст. Стамболов цени високо таланта и публицистичния дар на своя съратник, а Зах. Стоянов - куража на своя приятел да провежда самостоятелна политика, така както той я разбирал - нито русофилска, нито австрофилска, а българофилска.

И двамата неусетно попадат в мрежата на Кобурга, който се опитва под най-различни претексти да всее между тях недоверие и раздор. И само преждевременната кончина на Зах. Стоянов не му позволява да ги направи смъртни врагове, както това става с някои други лица от обкрьжението на Ст. Стамболов - Олимпий Панов, Коста Паница и пр.

${ }^{1}$ Тук ще се ограничим да посочим само някои заглавия. За Ст. Стамболов: Водовозов B. B. Стефан Стамболов. Пловдив, 1895; Биман А. Стефан Стамболов. - София, 1896; Маринов Д. Стефан Стамболов. Летописни спомени и очерки. - София, 1909; Велчев В. Т. Принос към новата ни история. Стамболов и Фердинанд. - София, 1922; Страшимиров А. Диктаторьт. Нови проучвания върху живота и личността на Стефан Стамболов. - София, 1935; Радев С. Строителите на съвременна България. - Т. 2. - София, 1973; Пантев А. Стефан Стамболов - хъшът, държавникът или „българският Бисмарк“. - София, 1994; Същият автор. Стефан Стамболов в часа на България. Статии, есета очерци. - София, 1995; Попов Р. България на кръстопът. Регентството 1886-1887. - София, 1991; Същият автор. Русия против Стамболов или Стамболов против Русия. - София, 2000; Иванов Д. Стефан Стамболов - от перото до ятагана. - София, 2005; Същият. Мъжка орис. - София, 2001; Същият. Стефан Стамболов - българската енергия. - София, 2006; Същият. Лидерът Стамболов. София, 2014, и др.; За Захарий Стоянов: Благоев Д. Захарий Стоянов като публицист, революционер, апостол и патриот. - София, 1886; Заимов Cm. Миналото. Етюди върху „Записките“ на 3. Стоянов. 
- София, 1895; Константинов Г. Захари Стоянов като публицист и писател. - София, 1952; Попиванов Ив. Захарий Стоянов. Биография. - София, 1969; Каранфилов Е. Най-българското време. Книга за „Записките“ на Захари Стоянов. - София, 1976, 1979; Чирпанлиев Cm. Медвенският размирник. Документална повест за детството на 3. Стоянов. - София, 1978; Същият автор. Захарий Стоянов. Биография. - София, 2002; Ташев Т. Животът на Летописеца. - Ч. 1: Джендо. - София, 1984; Същият автор. Животът на Летописеца. - Ч. 2: Парго. - София, 1989; Същчия автор. Животьт на Летописеца. - Ч. 3: Захарий. - София, 1989; и др.

${ }^{2}$ Бурмов Ал. Революционната дейност на Стефан Стамболов през 1873-1875 г. // Родина. - 1939. - № 2. - С. 76-94.

${ }^{3}$ Братоев Б. Панайот Вичев Волов. Биографичен очерк. - Шумен, 2001.

${ }^{4}$ Койчева В. Старозагорското въстание 1875. - София, 1975.

${ }^{5}$ По-подробно вж. Дойнов Д. Гюргевският революционен комитет. - София, 1986.

${ }^{6}$ Намереният преди време от нас препис от пълномощното на П. Волов и Г. Бенковски е подписано от Ст. Ст. Стамболов в качеството му на председател на Апостолското събрание, а не на какъвто и да било комитет (вж. Куманов М. За името на революционния орган в Гюргево в края на 1875 г. // Изследвания в чест на проф. Веселин Трайков. Studia Balkanica. - 2003. - № 24. - С. 173-183).

${ }^{7}$ По-подробно вж. Боршуков Г. История на българската журналистика 1844-1877 и 1878-1885. София, 1976; Иванов Д. Стефан Стамболов. Публицистика 1875-1895 // Стефан Стамболов. Личен архив. - Т. 18. -София, 1996.

${ }^{8}$ По-подробно вж. Генов Ц. Българската емиграция и националноосвободителното движение в навечерието на Руско-турската война от 1877-1878 г. // Исторически преглед. - 1968. - № 1. C. $75-94$.

${ }^{9}$ По-подробно вж. Иванов Д. Стефан Стамболов. Публицистика 1875-1895. - С. 45-72.

${ }^{10}$ По-подробно вж. Дойнов Д. Кресненско-Разложкото въстание 1878-1879. - София, 1979.

${ }^{11}$ По-подробно вж. Иванов Д. Стефан Стамболов Публицистика 1875-1895. - С. 73-84.

12 По-подробно вж. Стоянов Ив. Либералната партия в Княжество България (1879-1886). София, 1989

13 По-подробно вж. Димитров Ил. Преди 100 години. Съединението. - София, 1985.

${ }^{14}$ Стоянов Ив. Либералната партия... - С. 149-152.

${ }^{15}$ Вж. Иванов Д. Стефан Стамболов. Албум / Д. Иванов, М. Куманов. - София, 2005.

${ }^{16}$ По-подробно вж. Попов Р. България на кръстопът. Регентството 1886-1887. - София, 1991.

${ }^{17}$ По-подробно вж. Попов Ж. Бурният живот на Димитър Петков. - София, 1998. 